\title{
Corynespora cassiicola causes leaf spots on sweet basil (Ocimum basilicum) in Brazil
}

\section{Caio Mattos Pereira ${ }^{1} \cdot$ Sara Sarmiento Salcedo ${ }^{1} \cdot$ Eliza de Oliveira Lopes ${ }^{1} \cdot$ Robert Weingart Barreto $^{1}$}

Received: 26 August 2019 / Accepted: 4 October 2019/Published online: 20 October 2019

(C) Australasian Plant Pathology Society Inc. 2019

\begin{abstract}
Corynespora cassiicola is reported causing leaf spots on Ocimum basilicum (sweet basil) for the first time in Brazil. The fungus was identified based on morphological and molecular features and its pathogenicity to sweet basil was demonstrated.
\end{abstract}

Keywords Culinary herb $\cdot$ Dematiaceous fungi $\cdot$ Lamiaceae $\cdot$ New record

Sweet basil (Ocimum basilicum), known in Brazil as manjericão, is a perennial herb of the Lamiaceae, native from tropical Asia (Lorenzi and Matos 2002), cultivated worldwide as a culinary herb or a medicinal plant (Simpson and Ogorzaly, 2001). Despite the widespread use and importance of this crop in Brazil, there is little research-based published information available about sweet basil in the country, including the diseases which attack it. Most records of fungi on sweet basil, included in the main list of fungi on plants in Brazil (Mendes and Urben 2019), are either of saprophytes or opportunistic pathogens or fungi for which identity has not been properly resolved.

In May 2019 severe leaf spotting, which led to intense defoliation of sweet basil, was observed on plants kept in a demonstration garden for plant diseases (Infectarium) in the campus of the Universidade federal de Viçosa (Viçosa, state of Minas Gerais, Brazil). The disease started with small circular to irregular, dark brown dots on leaves which became larger and necrotic (1.4 to $2.6 \mathrm{~cm}$ diam), with an eye-spot appearance, spread over the lamina, but often concentrated along the margins, leading to a blight accompanied by yellowing of the leaves and defoliation of plants (Fig. 1A-B). A dematiaceous hyphomycete was regularly found sporulating on the lesions. A representative sample was dried in a plant press and deposited in the local herbarium at the Universidade Federal de

Robert Weingart Barreto

rbarreto@ufv.br

1 Departamento de Fitopatologia, Universidade Federal de Viçosa, Viçosa, MG 36570-900, Brazil
Viçosa, Viçosa, state of Minas Gerais, Brazil (Acc. No VIC 47345).

Fungal structuctures (conidia and conidiophores) were transferred from sporulating lesions onto potato dextrose-agar (PDA) plates with a sterile fine pointed needle and incubated at $25 \pm 2^{\circ}$ for nine days under a $12 \mathrm{~h}$ photoperiod. Pure cultures were obtained. A representative isolate was deposited in the local culture collection - Coleção Octávio de Almeida Drummond, of the Universidade Federal de Viçosa, Viçosa, state of Minas Gerais, Brazil (Acc. No COAD 2923). Fungal structures were also scraped with a scalpel, from sporulating lesions and mounted in lactoglycerol or lactofuchsyn on slides and observed under a light microscope (Olympus BX51) fitted with differential interference contrast (DIC) illumination and connected to a Olympus Q-color3 camera.

The fungus had the following morphology: conidiophores amphigenous, cylindrical, straight to slighlty curved 153 $646 \times 59 \mu \mathrm{m}, 3-11$ septate, pale brown and smooth; conidia solitary or in short acropetal chains, fusiform, obclavate to subcylindrical, straight or curved 112-314 $\times 4-8 \mu \mathrm{m}, 8-33$ distoseptate, sub- hyaline to pale brown, smooth, with 1-2 flat darkened and thickened hila. Colonies were relatively slowgrowing ( $5.3 \mathrm{~cm}$ diam after 9 days), umbonate, felty, edge entire, glaucous gray to mouse gray, sporulation scarce (Figs. 1C-E). Such morphological features were found to be similar to those described for Corynespora cassiicola in Ellis and Holliday (1971).

For molecular characterization, DNA was extracted from COAD 2923 using the Wizard® Genomic DNA Purification kit (Promega) according to the manufacturer's instructions. The internal trancribed spacer (ITS) region was amplified using the primer pairs ITS4/ITS5 (White et al. 1990). A BLASTn search of the resulting sequence (GenBank 
Fig. 1 Corynespora cassiicola on Ocimum basilicum. A Diseased plant bearing yellow leaves, spotted leaves and leaves with marginal blight. B Lesions on leaf of a sweet basil plant. C Colony growing on PDA. D

Conidiophore of Corynespora cassiicola. E Conidium. Bars = $50 \mu \mathrm{m}$ (D) $20 \mu \mathrm{m}$ (E)
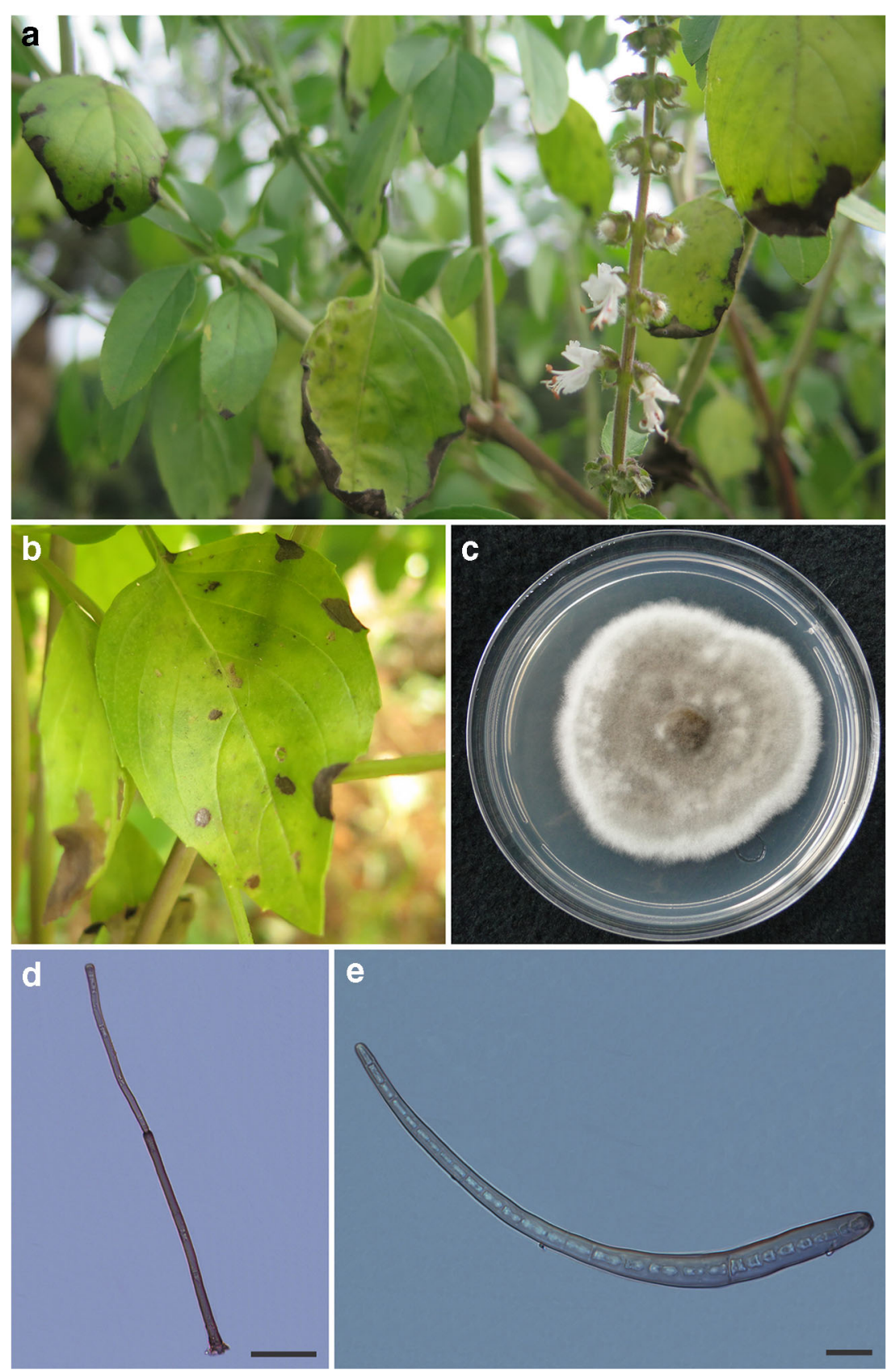

Accession No. MN400059) indicated a 99.63\% identity and no gaps with sequences of $C$. cassiicola deposited in GenBank (MH762895 and MH857942).

Pathogenicity was tested on healthy one-month-old basil plants. Six plants were sprayed with a $1 \times 10^{4}$ conidia/mL suspension of COAD 2923 until runoff. Four plants were sprayed with sterile water only and served as controls. After spraying all plants were kept in a humid chamber, for $48 \mathrm{~h}$, and subsequently transferred to a greenhouse bench. After two days, leaf spots were observed on inoculated plants but not on controls.
Corynespora cassiicola was reisolated from necrotic lesions of inoculated plants, therefore fulfilling Koch's postulates.

Corynespora cassiicola is widely distributed around the world and has a very broad host range including many economically important crops (Ellis and Holliday 1971, Dixon et al. 2009). It has been previously recorded as a pathogen of sweet basil from Brunei, Hawaii, Italy, Myanmar and Samoa (Farr and Rossman 2019), but, to our knowledge, this is the first report of $C$. cassiicola causing leaf spot on Ocimum basilicum in Brazil. 


\section{References}

Dixon LJ, Schlub RL, Pernezny K, Danoff LE (2009) Host specialization and phylogenetic diversity of Corynespora cassiicola. Phytopathology 99:1015-1027

Ellis MB, Holliday P (1971) Corynespora cassiicola. CMI Descr Pathog Fungi Bact 303:1-2

Farr DF, Rossman AY (2019) Fungal Databases, U.S. National Fungus Collections, ARS, USDA. https://nt.ars-grin.gov/fungaldatabases/. Accessed 25 Aug 2019

Lorenzi H, Matos FJA (2002) Plantas medicinais no Brasil: nativas e exóticas. Instituto Plantarum, Nova Odessa
Mendes MAS, Urben AF (2019) Fungos relatados em plantas no Brasil, Laboratório de Quarentena Vegetal. Brasília, DF: Embrapa Recursos Genéticos e Biotecnologia. http://pragawall.cenargen.embrapa.br/ aiqweb/michtml/fgbanco01.asp. Acessed 25 Aug 2019

Simpson B, Ogorzaly M (2001) Economic botany: Plants in our world. McGraw Hill, New York

White TJ, Bruns T, Lee S, Taylor J (1990) Amplification and direct sequencing of fungal ribosomal RNA genes for phylogenetics. In: Innis MA, Gelfand DH, Sninsky JJ (eds) PCR protocols: A guide to methods and amplifications. Academics press San Diego C.A. pp. 315-322 